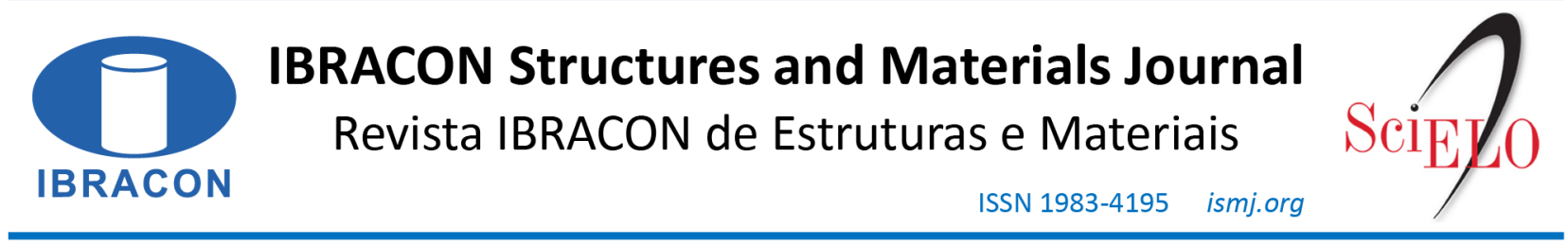

ORIGINAL ARTICLE

\title{
Thermal analysis of steel and concrete composite beams cross sections in fire situations
}

\section{Análise térmica de seções transversais de vigas mistas de aço e concreto submetidas a situação de incêndio}

\author{
Mateus de Souza Furriel Dias ${ }^{\mathrm{a}}$ (iD \\ Vânia José Karam ${ }^{a}$ (D)
}

${ }^{a}$ Universidade Estadual do Norte Fluminense Darcy Ribeiro, Civil Engineering Laboratory, Campos dos Goytacazes, Rio de Janeiro, Brazil

Received 01 March 2019

Accepted 28 July 2020

\begin{abstract}
The fire poses a considerable risk to human safety and, therefore, fire protection is a solution that should be incorporated into the construction system of a building. Composite beams, when subjected to fire, lose strength and stiffness due to the degradation of the mechanical properties of their materials. This paper aims to perform the thermal analysis of steel and concrete composite beams in fire situation. The software ABAQUS Version 6.14 [1] was used to develop numerical methods, whose results were analyzed and compared with the values obtained by the simplified calculation method prescribed in ABNT NBR 14323:2013 [2]. Thereby, the thermal behavior of the composite cross-section and the influence of the material and the type of fire protection were analyzed. The results showed that, for a certain type of protection and size of the metallic profile, the temperatures given by the Brazilian Standard may differ substantially from those obtained by numerical simulation.
\end{abstract}

Keywords: steel and concrete composite beams; numerical models; fire; fire protection.

Resumo: $\mathrm{O}$ incêndio constitui um risco considerável à segurança humana e, dessa forma, o revestimento contra fogo é uma solução que pode ser incorporada ao sistema construtivo de uma edificação. As vigas mistas, quando submetidas ao fogo, perdem resistência e rigidez devido à degradação das propriedades mecânicas de seus materiais. Este artigo tem como objetivo realizar a análise térmica de vigas mistas de aço e concreto em situação de incêndio. Foram elaborados modelos numéricos no software ABAQUS Versão 6.14 [1], cujos resultados foram analisados e comparados com valores obtidos pelo método simplificado de cálculo prescrito na ABNT NBR 14323:2013 [2]. Com isso, analisou-se o comportamento térmico da seção transversal mista e a influência do material e do tipo de revestimento contrafogo. Os resultados mostraram que, para certo tipo de revestimento e tamanho do perfil metálico, as temperaturas previstas pela Norma Brasileira podem diferir substancialmente daquelas obtidas pela simulação numérica.

Palavras-chave: vigas mistas aço e concreto; modelagem numérica; incêndio; revestimento contrafogo.

How to cite: M. S. F. Dias, V. J. Karam, “Thermal analysis of steel and concrete composite beams cross sections in fire situations," IBRACON Struct. Mater. J., vol. xx, no. xx, elocation, year, https://doi.org/10.1590/S1983-41952021000500009

\section{INTRODUCTION}

The structural systems composed of composite elements of steel and concrete aim to make the most of the advantages of each of these materials and bring some advantages, such as material savings and ease of execution. Composite steel and concrete beams emerged because of the use of steel beams underneath concrete slabs. The interaction between these two elements is guaranteed by metallic elements known as shear connectors.

Composite beams, when exposed to high temperatures, during typical fire conditions, have reduced mechanical strength and stiffness, which can cause all or part of the construction to collapse. In view of this, active or passive protections were developed, making it possible, to safely vacate the places that are part of a building of interest. Under 
this assumption, the verification of composite steel and concrete structures in fire situation becomes an important step in the execution of projects. It is important to highlight that an analysis in a fire situation must be done thinking about the overall behavior of the structure and not only in terms of isolated elements.

The first research on composite steel and concrete beams were carried out using experimental models. Furnace tests, despite being an essential part of understanding structural fire behavior, are still expensive and time-consuming [3], which is why, on many occasions, numerical models are built that, once validated, allow obtaining various types of information, such as thermal fields, displacements, and stresses. Therefore, many research have been developed and published to analyze the behavior of composite structures in fire situations based on a numerical response. Among the existing tools for numerical analysis, stand out specific computer packages for structures in fire situations and commercial packages developed based on the Finite Element Method (FEM), which make it possible to reproduce the behavior of a structure.

Concern about the safety of structures in fire situation has been around for a long time in many European countries and in the United States. However, although fire is an extremely important issue, the concern in designing fire-resistant structures is recent in the Brazilian context.

One of the first finite element programs for the analysis of steel plane frames at high temperatures was designed by Jain and Rao [4], considering the change in material properties due to temperature increase, creep effect and large deformations. In the early 1990s, Burgess et al. [5] developed a numerical procedure that analyzed cross-sections of metallic beams, considering that the thermal and mechanical properties of steel changed with the non-linearity of the temperature along the cross-section. On passive protections, Wang [6] presented experimental and numerical results, proposing a new model that aimed to reduce the cost of fire protection coating material in composite beams.

The SAFIR software, a specific computer program for modeling structures in fire situation, was used in Cazeli et al. [7], in which numerical analyzes were carried out on steel beams in a fire situation, subject to the phenomenon of lateral buckling. Wong and Ghojel [8] analyzed heat transfer formulations in relation to fire-coated steel elements and noticed that, for certain types of fire protection coating materials, the temperatures calculated using EN 1993-1-2:2005 [9] differed substantially from those calculated using analytical solutions. Ribeiro [10] developed a computational algorithm for performing transient and nonlinear thermal analysis of two-dimensional and threedimensional models of composite structural elements, based on the Finite Element Method. The results obtained were compared with the results found using the procedures of the main text of the revision of the standard ABNT NBR 14323:1999 [11], elaborated in 2003. In Rodrigues [12], a numerical and analytical study was carried out on the behavior of composite beams in fire situation, analyzing the fire phenomenon, its types of models, the degradation of steel properties with the temperature increase, thermal insulation of structures and the mechanisms of heat transmission.

Numerical models of composite steel and concrete partially coated beams were developed, in Rocha and Munaiar Neto [13], using the computational package DIANA, to evaluate the thermal and structural performance of this construction system. Fischer and Varma [14] developed 3D finite element models to predict the behavior and failure of composite beams in fire situations, which include both heating and cooling phases. A computational tool was developed, in Melão [15], able to calculate the resistant stress and temperatures of steel beams at room temperature and in fire situation, according to Brazilian Standards, including ABNT NBR 14323:2013 [2].

In this paper, two-dimensional numerical models of composite steel and concrete beams in fire situation are elaborated in the commercial software ABAQUS Version 6.14 [1], developed based on the Finite Element Method (FEM). The objective, based on the development of these models, is to perform thermal analysis of composite beams without and with fire protection coating of the contour and box types. The results obtained from the numerical models are compared with the results obtained through the simplified calculation method proposed in ABNT NBR 14323:2013 [2], to analyze the possible differences between these methods in the temperatures of the steel profile, shear connector and concrete slab. In this comparison, steel profiles with different dimensions are analyzed to verify the influence of the profile size on the evolution of the steel "temperature vs time" curve. This analysis is justified by the lack of papers that use this most recent standard and compare the results with variations in the profiles sizes.

Also, in this context, a new equation is proposed to determine the mass factor of the profile web in situations without fire protection and with contour-type fire protection coating, as a normative contribution. An analysis of the thermal behavior of the cross-section of the composite beam without fire protection is made from the results of the modeling, to verify the evolution of the temperature field and the heat flow during the time of exposure to fire. The maximum temperature points in each part of the composite section, the effect of the profile mass factor on the temperature rise and the efficiency of the type of fire protection coating on the steel profile and concrete slab are identified. In addition, the profile dimensions and the properties of the fire protection coating material that most influence the heat rise rate of the composite beam are evaluated. 


\section{ASPECTS ADOPTED IN STEEL AND CONCRETE COMPOSITE BEAM MODELS}

The thermal analysis of a structural element in fire situation corresponds to the verification of the development and distribution of the temperature field due to the heat transfer between the hot gases of the fire and the structure.

Each composite beam cross-section used in this project consists of a concrete slab with a flat bottom face, supported on the upper flange of the steel I-beam, containing or not the shear stud bolt connector. This is because, for the composite beam, a cross-section that passes through the shear connector and a section that does not pass through the connector were considered. Therefore, the disregard of the connector in the studied model occurs only in the thermal analysis of the composite section and this does not mean that composite beam does not have connectors between the steel profile and the concrete slab.

At this step of the thermal analysis, it is assumed that the part of the structural element that is totally immersed in the flames of the compartment, that is, where are located the steel beam and the bottom face of the concrete slab, is called "side exposed to fire", and the upper face of the slab is called "side not exposed to fire", where there is no fire, and the air is at room temperature. Figure 1 illustrates the composite beam parts and the regions exposed to fire and room temperature.

To determine the temperature of the structural element in a fire situation, the "temperature $x$ time" curve of the hot gases, called standard fire, can be used together with the required time of fire resistance (RTFR), as determined in ABNT NBR 14323:2013 [2]. The ABNT NBR 5628:2001 [16] recommends the use of the following equation to determine the "temperature $\mathrm{x}$ time" curve of the standard fire:

$\theta_{g}=\theta_{g 0}+345 \log (8 t+1)$

where $t$ is the time, in minutes; $\theta_{g}$ is the gas temperature in the fire environment, in ${ }^{\circ} \mathrm{C}$; and $\theta_{g 0}$ is the gas temperature at the instant $t=0$, in ${ }^{\circ} \mathrm{C}$. The RTFR, according to ABNT NBR 14432:2001 [17], is the minimum time that a constructive element must resist fire when subjected to standard fire and can vary from 30 to 120 minutes.

The steel beam profiles (VS Series) used are welded and have dimensions specified by ABNT NBR 5884:2013 [18]. The steel beam profiles are: composite beam 1 - VS 350 x 42; composite beam 2 - VS 650 x 155; composite beam 3 VS $250 \times 32$; composite beam 4 - VS $450 \times 60$. The choice for this type of profile is related to the greater flexibility of specifications and variety of sizes, making it possible to obtain profiles with different dimensions. Figure 2 shows the nomenclatures of the dimensions of the composite beam. It is important to point out that the profiles of the composite beams 2, 3 and 4 were chosen in order that they had different thicknesses and lengths of the flanges and web and that the dimensional variations were not disproportionate. Thus, it was considered that the steel profile of the composite beam 4 was intermediate to the steel profiles of the composite beams 2 and 3 . All the slabs used in the composite beams have an effective width, $\mathrm{W}$, equal to $1 \mathrm{~m}$ and a height, $\mathrm{H}$, equal to $0.1 \mathrm{~m}$. The connector used, illustrated in Figure 3 , is the stud bolt and its dimensions are based on the Inox-Par M19 connector.

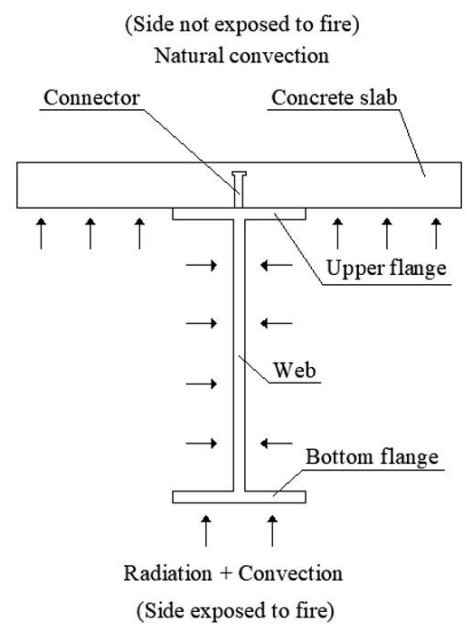

Figure 1. Proposed model of composite steel and concrete beam in a fire situation. 


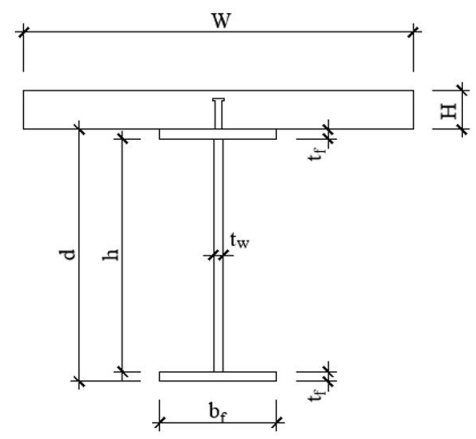

Figure 2. Nomenclatures of the dimensions of composite beam cross-section.

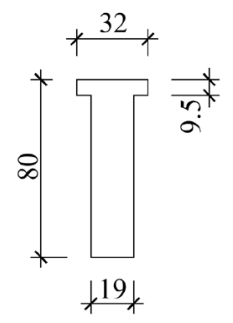

Figure 3. Dimensions of stud bolt connector, in $\mathrm{mm}$.

For this project, contour and box types of fire protection coating were used for the steel profiles (without gaps), with thickness $t_{m}$, as shown in Figure 4.

Each cross-section of composite steel and concrete beam is indicated by its number followed by acronyms according to its boundary conditions, as follows:

- NP-C: has no fire protection coating and contains the stud bolt connector;

- NP-NC: has no fire protection coating and does not contain the stud bolt connector;

- CP-NC: has a contour-type fire protection coating and does not contain the stud bolt connector;

- BP-NC: has a box-type fire protection coating and does not contain the stud bolt connector.
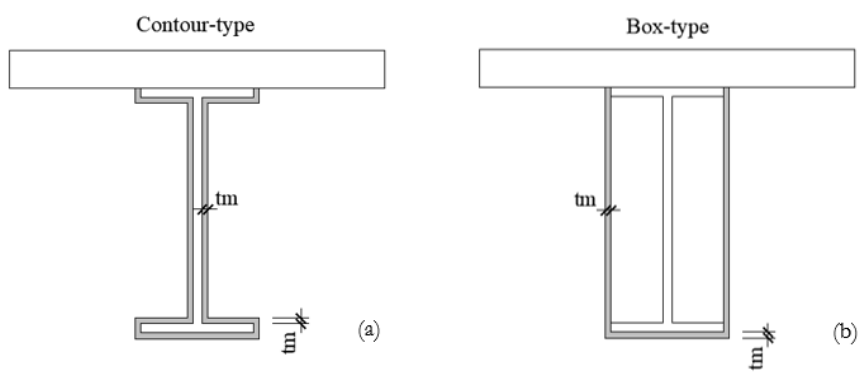

Figure 4. Fire protection coating: (a) contour-type and (b) box-type.

In all models, a resulting emissivity, $\varepsilon_{r e s}$, equal to 0.7 , was adopted for steel and fire protection coating material. This value is standardized by the ABNT NBR 14323:2013 [2], although it mentions this value only for the emissivity resulting from steel. In accordance with recommendations prescribed in EN 1992-1-2:2004 [19], for the concrete, a resulting emissivity, $\varepsilon_{r e s}$, equal to 0.7 was adopted. The convective heat transfer coefficient, $\alpha_{c}$, on the side exposed to standard fire, was adopted equal to $25 \mathrm{~W} / \mathrm{m}^{2} \cdot{ }^{\circ} \mathrm{C}$, as prescribed in ABNT NBR 14323:2013 [2]. Regarding the concrete slab, the heat exchange between the surface not exposed to fire and the environment was considered through an $\alpha_{c}$ coefficient equal to $9 \mathrm{~W} / \mathrm{m}^{2} \cdot{ }^{\circ} \mathrm{C}$, according to recommendations prescribed in EN 1991-1-2:2002 [20]. For all composite beams, the initial temperature adopted in the cross-section was $20^{\circ} \mathrm{C}$, as standardized by the ABNT NBR 14323:2013 [2]. 
The thermal properties, such as specific heat and thermal conductivity, and the specific mass of the materials vary with temperature, however, simplified values of the properties of steel and concrete were used, as prescribed by ABNT NBR 14323:2013 [2] and ABNT NBR 15200:2012 [21], respectively, which are independent of temperature. The properties of the fire protection coating material used have similar values to the properties of ceramic fiber coatings, which are currently commercialized. The suppliers of these materials specify constant values for thermal properties, that is, they do not vary depending on the temperature. The same fire coating material was used to modeling composite beams with both contour and box fire protection types. The values of the properties and thickness of the steel, concrete and fire protection coating materials are shown in Table 1.

Table 1. Properties of the steel, concrete, and fire protection coating materials.

\begin{tabular}{cccc}
\hline Properties & \multicolumn{3}{c}{ Material } \\
\cline { 2 - 4 } & Steel & Concrete & Coating \\
\hline Specific mass $\left(\mathrm{kg} / \mathrm{m}^{3}\right)$ & 7850 & 2400 & 320 \\
\hline Specific heat $\left(\mathrm{J} / \mathrm{kg} \cdot{ }^{\circ} \mathrm{C}\right)$ & 600 & 1000 & 1100 \\
\hline Thermal conductivity $\left(\mathrm{W} / \mathrm{m}^{\circ}{ }^{\circ} \mathrm{C}\right)$ & 45 & 1.30 & 0.135 \\
\hline Thickness $(\mathrm{mm})$ & - & - & 13 \\
\hline
\end{tabular}

In the numerical model of the composite beam with box-type fire protection coating, it was considered that the mechanism of heat transmission that predominates inside the cavity is only the heat conduction through the air, differently from what is considered in ABNT NBR 14323:2013 [2], where the existence of air is neglected. The values of the thermal properties of the air are shown in Table 2.

\section{CALCULATION METHODOLOGY AND NUMERICAL MODELING}

The models used in this paper to obtain the temperature evolution in the cross-section of the composite beam are the simplified and advanced calculation models. The simplified calculation model refers to the simplified equations of ABNT NBR 14323:2013 [2], which allow to obtain the temperature rise in a homogeneous way for each part of the cross-section. The advanced calculation model refers to the resolution of the problem through numerical simulation performed using the ABAQUS version 6.14 calculation code [1], which provides the researcher with the necessary resources for the modeling in question.

In the next items, conceptual aspects and procedures related to obtaining the temperature rise in the composite beams will be presented.

Table 2. Air properties inside the cavity of the box-type fire protection coating, Ribeiro [10].

\begin{tabular}{cccc}
\hline Temperature $\left({ }^{\circ} \mathbf{C}\right)$ & Specific mass $\left(\mathbf{k g} / \mathbf{m}^{\mathbf{3}}\right)$ & Specific heat $\left(\mathbf{J} / \mathbf{k g} \cdot{ }^{\circ} \mathbf{C}\right)$ & $\begin{array}{c}\text { Thermal conductivity } \\
\left(\mathbf{W} / \mathbf{m} \cdot{ }^{\circ} \mathbf{C}\right)\end{array}$ \\
\hline 20 & 1.17 & 1000 & 0.025 \\
\hline 100 & 0.94 & 1012 & 0.032 \\
\hline 180 & 0.78 & 1025 & 0.038 \\
\hline 260 & 0.65 & 1040 & 0.043 \\
\hline 340 & 0.56 & 1056 & 0.048 \\
\hline 420 & 0.50 & 1073 & 0.052 \\
\hline 500 & 0.45 & 1090 & 0.056 \\
\hline 580 & 0.41 & 1107 & 0.060 \\
\hline 740 & 0.38 & 1125 & 0.063 \\
\hline 820 & 0.35 & 1141 & 0.067 \\
\hline 980 & 0.32 & 1158 & 0.071 \\
\hline 1060 & 0.30 & 1173 & 0.075 \\
\hline & 0.27 & 1188 & 0.080 \\
\hline
\end{tabular}




\subsection{Simplified calculation method of thermal analysis}

ABNT NBR 14323:2013 [2] standardized a simplified method of calculation that aims to determine the thermal action and design of steel structures and composite structures of steel and concrete in fire situation. The simplified method of thermal analysis is applicable to structural steel elements with and without fire protection coating material, located inside the building, fully immersed in the fire environment.

For a uniform temperature distribution in the cross-section, the increase of temperature $\Delta \theta_{a, t}$, in ${ }^{\circ} \mathrm{C}$, of the steel without fire protection coating over the time interval $\Delta t$, in seconds, can be determined by:

$$
\Delta \theta_{a, t}=0.9 \frac{\left(u / A_{g}\right)_{b}}{\left(u / A_{g}\right)} \times \frac{\left(u / A_{g}\right)}{c_{a} \rho_{a}} \varphi \Delta t
$$

where $u$ is the perimeter of the steel structural element exposed to fire, in $\mathrm{m} ; A_{g}$ is the cross-sectional area of the steel structural element, in $\mathrm{m}^{2} ;\left(u / A_{g}\right)$ is the mass factor for steel structural elements without fire protection coating, in $\mathrm{m}^{-1}$; $\left(u / A_{g}\right)_{b}$ is the value of the mass factor defined as the ratio between the perimeter exposed to the fire of a hypothetical box that surrounds the profile and the cross-sectional area of the profile, in $\mathrm{m}^{-1} ; \rho_{a}$ is the specific mass of the steel, in $\mathrm{kg} / \mathrm{m}^{3}$; and $c_{a}$ is the specific heat of the steel, in $\mathrm{J} / \mathrm{kg} \cdot{ }^{\circ} \mathrm{C}$.

The heat flow value $\varphi$, in $\mathrm{W} / \mathrm{m}^{2}$, is given by:

$\varphi=\varphi_{c}+\varphi_{r}$

with

$\varphi_{c}=\alpha_{c}\left(\theta_{g}-\theta_{a}\right)$

and

$\varphi_{r}=5.67 \times 10^{-8} \varepsilon_{r e s}\left[\left(\theta_{g}+273\right)^{4}-\left(\theta_{a}+273\right)^{4}\right]$

where $\varphi_{c}$ is the component of the heat flow due to convection, in $\mathrm{W} / \mathrm{m}^{2} ; \varphi_{r}$ is the component of the heat flow due to radiation, in $\mathrm{W} / \mathrm{m}^{2} ; \theta_{a}$ is the temperature on the steel surface exposed to fire, in ${ }^{\circ} \mathrm{C} ; \theta_{g}$ is the temperature of the gases, in ${ }^{\circ} \mathrm{C} ; \varepsilon_{r e s}$ is the resulting emissivity; and $\alpha_{c}$ is the convection heat coefficient, in $\mathrm{W} / \mathrm{m}^{2} \cdot{ }^{\circ} \mathrm{C}$.

In steel profiles with fire protection coating, the heat reaching the steel depends on the conduction through the protection coating material, unlike what occurs in the elements without fire protection coating, in which the heat is transmitted by convection and radiation. Consequently, for a uniform temperature distribution in the cross-section, the temperature rise $\Delta \theta_{a, t}$, in ${ }^{\circ} \mathrm{C}$, of the steel surrounded by a fire protection coating material during a time interval $\Delta t$, in seconds, can be determined by:

$\Delta \theta_{a, t}=\frac{\lambda_{m}\left(\frac{u_{m}}{A_{g}}\right)\left(\theta_{g, t}-\theta_{a, t}\right)}{t_{m} \rho_{a} c_{a}\left(1+\frac{\xi}{4}\right)} \Delta t-\frac{\Delta \theta_{g, t}}{\frac{4}{\xi}+1}$

where $\Delta \theta_{a, t} \geq 0$ if $\Delta \theta_{g, t}>0$ 
with

$\xi=\frac{c_{m} \rho_{m}}{c_{a} \rho_{a}} t_{m}\left(\frac{u_{m}}{A_{g}}\right)$

where $u_{m}$ is is the effective perimeter of the fire protection coating material, in $\mathrm{m} ;\left(u_{m} / A_{g}\right)$ is the mass factor for structural steel elements with fire protection coating material, in $\mathrm{m}^{-1} ; c_{m}$ is the specific heat of the fire protection coating material, in $\mathrm{J} / \mathrm{kg} \cdot{ }^{\circ} \mathrm{C} ; \lambda_{m}$ is the thermal conductivity of the fire protection coating material, in $\mathrm{W} / \mathrm{m} \cdot{ }^{\circ} \mathrm{C} ; \rho_{m}$ is the specific mass of the fire protection coating material, in $\mathrm{kg} / \mathrm{m}^{3}$; and $t_{m}$ is the thickness of the fire protection coating material, in m.

The time interval $\Delta t$ was adopted as 5 seconds for all analyzed cases. When the steel profile is not surrounded by fire protection coating material or has a contour-type fire protection coating, the temperature distribution in the steel profile must be taken as non-uniform. In this way, the cross-section is divided into three parts: bottom flange, web and upper flange. In this case, it is considered that there is no heat transfer between these parts or between the upper flange and the concrete slab. Therefore, the mass factor $u / A_{g}$ or $u_{m} / A_{g}$, in $\mathrm{m}^{-1}$, must be equal to:

- For the bottom flange: $2\left(b_{f}+t_{f}\right) / b_{f} t_{f}$

- For the upper flange overlaid with solid slab: $\left(b_{f}+2 t_{f}\right) / b_{f} t_{f}$

- For the web: $2 h / t_{w}$ with $b_{f}, t_{f}, h$ and $t_{w}$ in meters.

For steel components with box-type fire protection coating, a uniform temperature can be considered in the profile.

Regarding the concrete slab, it is considered that the temperature distribution is constant along the effective width and the temperature variation in the slab height can be obtained from Table A.1 of ABNT NBR 14323:2013 [2], dividing the slab height into a maximum of 14 slices. In a simplified form, it can be considered the uniform temperature along the height of the concrete slab, and equal to:

$\theta_{c}=\frac{1}{H} \sum_{j=I}^{n} \theta_{c, j} e_{j}$

where $n$ is the number of slices into which the slab was divided; $H$ is the thickness of the concrete slab, in mm; $\theta_{c, j}$ is the temperature, in ${ }^{\circ} \mathrm{C}$; and $e_{j}$ is the thickness of a slice $j$, in $\mathrm{mm}$.

\subsection{Numerical modeling in the software ABAQUS}

The study of the thermal behavior of composite beams in fire situation through numerical simulations allows more detailed analysis of some aspects of interest to the composite system, such as, for example, the field and temperature evolution, thermal gradients, and thermal flows in a certain region. Thus, two-dimensional models of composite beams are proposed to satisfactorily simulate their thermal behavior in fire situation.

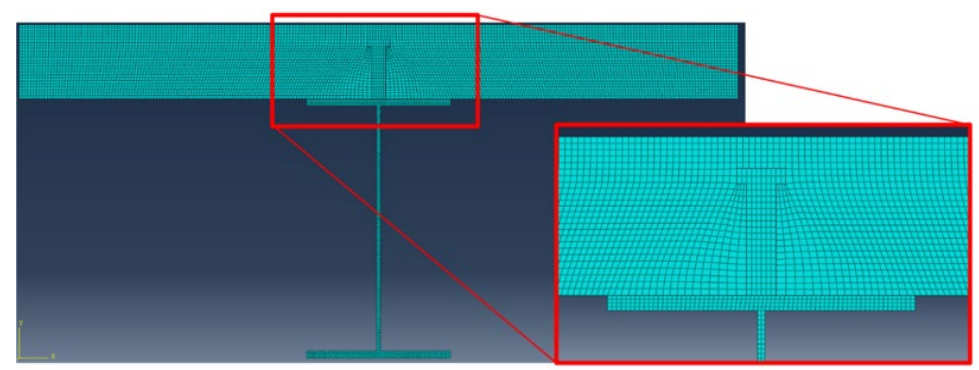

Figure 5. Finite element mesh of the composite beam 1 (NP-C). 
In this paper, all parts of the structural element were defined as solid, homogeneous, and two-dimensional elements. The finite element used in the discretization of the entire composite beam is DC2D4, a 4-node quadrilateral element belonging to the heat transfer family. It is important to highlight that the finite element meshes were designed so that there was node located exactly at each point where it is desired to determine the temperature. Several meshes, less and more refined, were considered, observing that, after a certain degree of mesh refinement, the results converged to the presented results. For each model of composite beam simulated in ABAQUS, a different mesh was used, due to the variations of the sizes of the steel profile. The Figure 5 illustrates the mesh of the composite beam 1 (NP-C).

An analysis step of 7200 seconds was created for a transient response, with an increment of 60 seconds, which makes it possible to determine the distribution and values of temperatures as a function of time.

In the amplitude of the temperature reached in the composite beam contour, the "temperature $\mathrm{x}$ time" curve of the "Standard Fire" was respected, establishing a maximum gas temperature equal to $1049^{\circ} \mathrm{C}$. Thus, were introduced the thermal interactions of the composite beam with hot gases and gases at room temperature, and of the steel profile with the concrete slab, with the fire protection coating material and with the air present in the box-type fire protection coating. The temperatures are expressed from the scale of temperature in Celsius degrees, considering, in this case, the absolute temperature equal to $-273.15^{\circ} \mathrm{C}$, and the Stefan-Boltzmann constant equal to $5.67 \times 10^{-8} \mathrm{~kW} / \mathrm{m}^{2} \cdot \mathrm{K}^{4}$.

In the numerical modeling of these composite beams in ABAQUS, it was considered that there is heat exchange between the parts of the metallic profile (bottom flange, upper flange and web) and also between the upper flange and the concrete slab.

\section{RESULTS AND DISCUSSIONS}

As a result of the thermal analysis, the evolution and distribution of the temperature field is observed in the crosssection of the entire composite beam. The results of the analysis were divided into four stages: analysis of the thermal behavior of the composite beam cross-section, comparative thermal analysis (ABAQUS vs ABNT NBR 14323:2013), analysis of composite beams without fire protection coating material and analysis of composite beams with fire protection coating material.

\subsection{Analysis of the thermal behavior of the composite beam cross-section}

This analysis, carried out using ABAQUS program, aims to describe the thermal behavior of the cross-section of the composite beam 1 in fire situation, without fire protection coating and with the stud bolt connector at the interface between the profile and the concrete slab. The analysis was made only in this composite beam because the evolution of the temperature field and the heat flow are maintained with the same pattern in other cross-sections of the same model.

\subsubsection{Temperature field of the cross-section}

With the temperature field, it is possible to analyze the temperature distribution along the cross-section, observing the regions that have higher temperatures. Figure 6 shows the temperature field of the composite beam 1 (NP-C) in 120 minutes of fire duration.

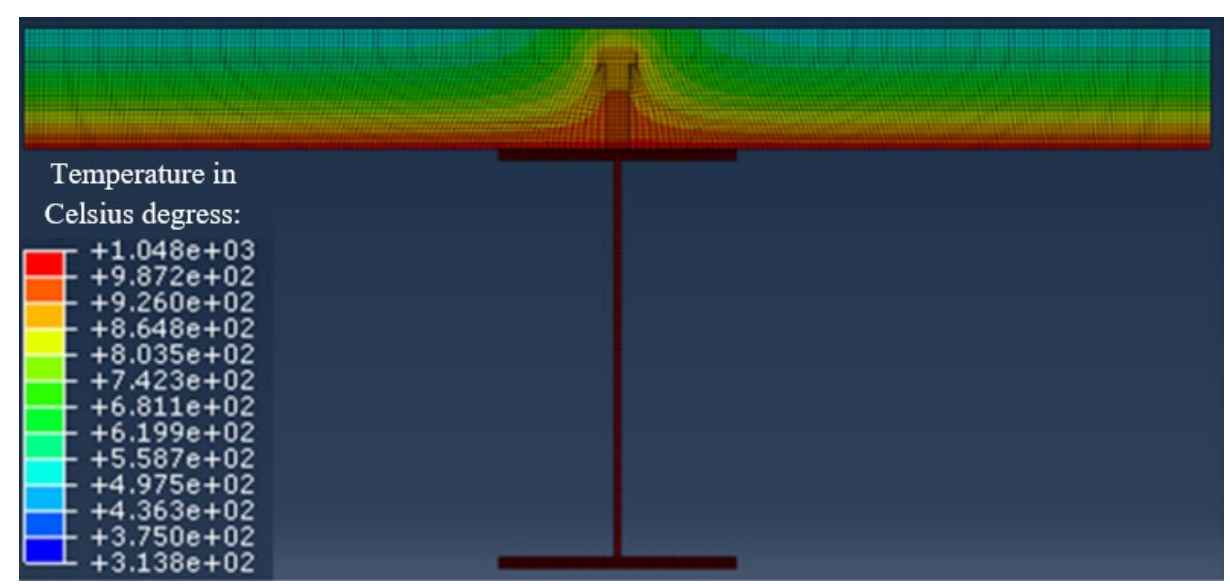

Figure 6. Temperature field $\left({ }^{\circ} \mathrm{C}\right)$, in 120 minutes of fire duration, of the composite beam 1 (NP-C). 
The temperature field in the concrete slab is uniform along the effective width, except in the region that contains the connector, due to the difference in thermal conductivity between steel and concrete. The concrete slab temperature is higher on the surface exposed to the fire and decreases as it approaches the surface in contact with room temperature. It is observed that the steel profile presented the highest temperatures in the composite section and that the connector does not have a uniform temperature along its height.

\subsubsection{Temperature distribution at specific points}

It is possible to analyze the temperature field in more detail using the temperature values calculated at certain specific points and observe the difference in the temperature gradient in each specific part of the composite beam. Figure 7 shows temperature values at fifteen specific points in the composite section during the fire duration times of 30 and 60 minutes for the composite beam 1 (NP-C).

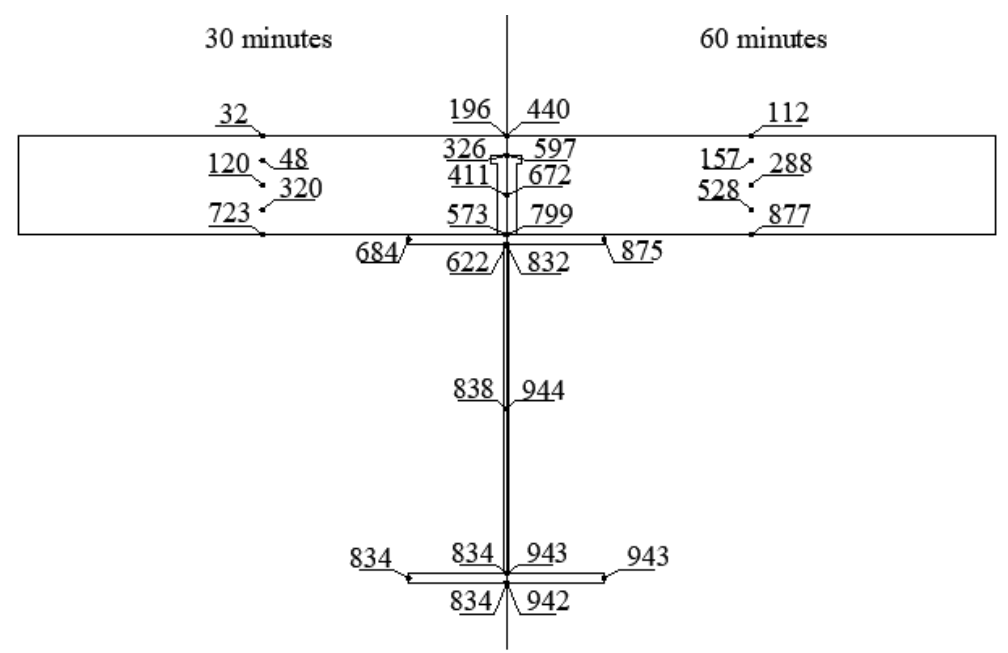

Figure 7. Distribution of temperatures $\left({ }^{\circ} \mathrm{C}\right)$ in the composite beam 1 (NP-C) for the fire duration times of 30 and 60 minutes.

The upper flange, as it was not fully exposed to fire due to the presence of the concrete slab, reached the lowest temperatures of the steel profile. All regions of the bottom flange had the same temperature for a certain time of fire. The web, in addition to having the highest temperature in the cross-section, had a non-uniform temperature distribution along its length. The temperature of the connector was higher in the region closest to the upper flange due to the conduction of heat between these two parts. The maximum temperature regions $\theta_{\max }$ of each part of the composite beam and the concrete slab sections for thermal analysis are shown in Figure 8.

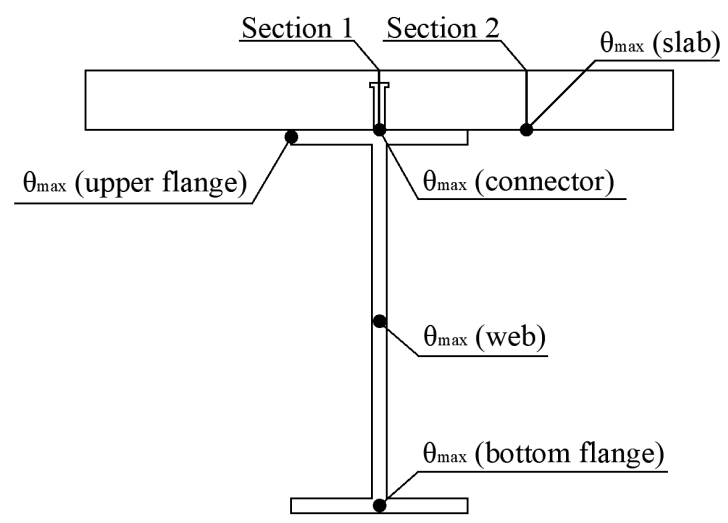

Figure 8. Maximum temperature regions of the composite cross-section parts. 


\subsection{3 "Temperature $x$ time" curves}

The "temperature $\mathrm{x}$ time" curves make it possible to observe the temperature evolution of a certain point in the cross-section over time. The points chosen for analysis are those with the maximum temperature of the flanges, web, concrete slab and connector. The "temperature $\mathrm{x}$ time" curves of these regions of the composite beam 1 (NP-C), the upper flange of the composite beam 1 (NP-NC) and the standard fire are shown in Figure 9.

The temperature of the entire composite beam increases with time, as does the temperature of the gases in fire situation. The "temperature $\mathrm{x}$ time" curves of the web and the bottom flange had a more pronounced elevation in comparison to the other parts of the section in the first 20 minutes, until reaching the temperature equal to that of atmospheric air. The maximum temperature of the concrete slab develops faster than the temperature of the upper flange in the first 50 minutes, and then the curves of these parts become similar. The connector was the element that had the lowest maximum temperature during the entire fire duration.

\section{Composite beam 1}

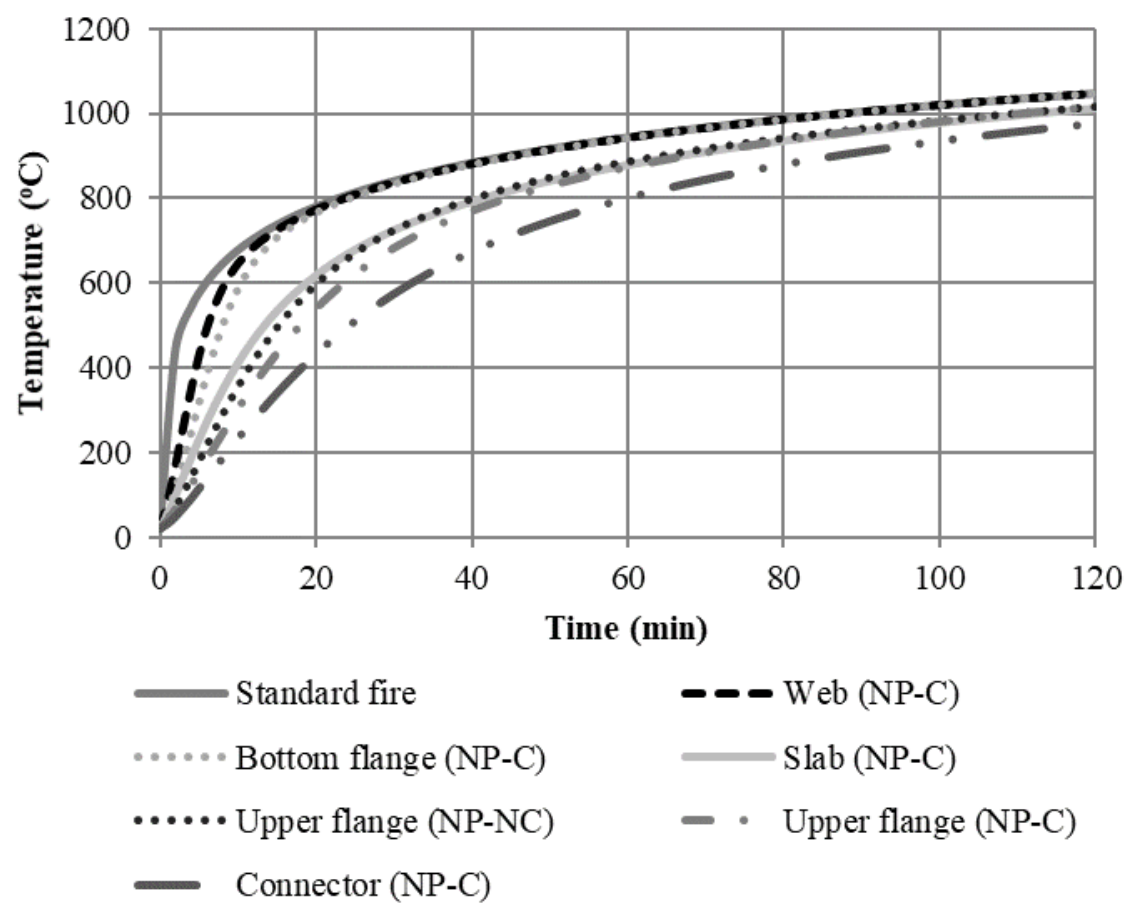

Figure 9. "Temperature $x$ time" curves of the parts of the composite beam 1 and standard fire.

In the "temperature $x$ time" curve of the center of the upper flange of the composite beam 1 (NP-NC), in the section without the presence of the shear connector, it can be observed that the maximum temperature reached was higher than the maximum temperature of the upper flange in the section where there is a connector. This shows that the presence of the shear connector increased the heat flow from the upper flange, causing a decrease in the temperature on the flange. Therefore, since the flange temperature of the steel profile of the composite beam 1 was analyzed in two crosssections (with and without the shear connector), the thermal analyzes can be done without the presence of the connector and considering the maximum temperature of the upper flange at its center.

\subsection{Comparative thermal analysis: ABAQUS x ABNT NBR 14323:2013}

The purpose of this analysis is to compare the results obtained by the numerical modeling performed at ABAQUS with those obtained by the simplified method proposed in ABNT NBR 14323:2013 [2]. In this analysis, it is possible to compare the temperature of the cross-section of the composite beams 1,2 and 3 at various times of the fire duration 
in three situations: profile without fire protection coating, profile with contour-type fire protection coating and profile with box-type fire protection coating.

\subsection{1 "Temperature $x$ time" curves}

For this step, the composite beam 2, with larger dimensions, and the composite beam 3, with smaller dimensions, were chosen to verify if the difference in the size and linear mass of the profile generates any influence in the comparison of its curves. The Equation (10) determined in ABNT NBR 14323:2013 [2] to calculate the mass factor of the web of the steel profile is dimensionless, that is, it does not have the correct unit representing the mass factor that is $\mathrm{m}^{-1}$. It is also possible to verify that, when the mass factor of the web, $\left(u / A_{g}\right)$, is determined, considering the ratio of its perimeter by the area of its cross-section, the following equation is found:

$$
\text { Mass Factor }=\frac{2 \times\left(h+t_{w}\right)}{h \times t_{w}}
$$

where $h$ and $t_{w}$ are in meters and the final unit of the mass factor is in $\mathrm{m}^{-1}$.

Therefore, it is believed that the Equation (10), obtained from the standard, is incorrect. Thus, the "temperature $\mathrm{x}$ time" curve of the web was calculated using the ABNT NBR 14323:2013 [2] method, using the Equation (10), and the method proposed in this paper, applying the Equation (12), for the profile without fire protection coating and with contour-type fire protection coating. With respect to the upper and bottom flanges of the steel profile, Equations (8) and (9), obtained from the standard, provide the correct unit of mass factor, respecting the $\left(u / A_{g}\right)$ ratio, and it is not necessary to propose a new equation for these parts of the steel profile.

Figures 10, 11, and 12 show the "temperature $\mathrm{x}$ time" curves from the two calculation methods to the parts of the steel beam, in the case of the profile without a fire protection coating, with a contour-type fire protection coating and with a box-type fire protection coating, respectively.

\subsubsection{Profile without fire protection coating}

The "temperature x time" curve for composite beams without fire protection coating can be seen in the Figure 10 .

Concerning to the bottom flange, the temperature obtained by ABAQUS was higher than the temperature obtained using the method proposed by the standard around the first 40 minutes. The difference in the curves obtained through these two methods was more significant in the profile of the composite beam 2 (NP-NC), and, after that, the two "temperature x time" curves were equal. Given these results, there was a greater similarity of the curves as the dimensions of the bottom flange became smaller.

With respect to the web, the curve obtained by ABAQUS was higher than the curve obtained using the standard method and this difference was smaller in the composite beam 2 (NP-NC). However, the ABAQUS curve was closer to the curve obtained with a change in the equation of the mass factor of the web, for all profiles analyzed. This shows that the use of the Equation (12) provides profile temperatures closer to the temperatures obtained by numerical modeling.

Regarding the upper flange, the "temperature $\mathrm{x}$ time" curve obtained by ABAQUS was higher than the curve obtained by the standard equation in the first 40 minutes and 20 minutes for the profile of the composite beams 2 (NP-NC) and 3 (NP-NC), respectively. After that time, the curve obtained by the standard method remains slightly higher.

\subsubsection{Profile with contour-type fire protection coating}

In Figure 11, the "temperature x time" curves can be observed for the composite beams with contour-type fire protection coating.

The "temperature $x$ time" curves of the bottom flange are very close to each other, mainly for the lighter profile, used in the composite beam 3 (CP-NC).

In the web, there was a more prominent difference between the curves obtained by ABAQUS and standard equation, which is more evident in the composite beam 3 (CP-NC), and the curves tended to be closer as the profile became larger, as the case of composite beam 2 (CP-NC). The results obtained by the simplified method with alteration in the 
equation of the web mass factor overestimate the results obtained by ABAQUS, and were closer to the composite beam 2 (CP-NC).

In relation to the upper flange, the curves are similar in the profile of the composite beam 2 (CP-NC), while in the profile of the composite beam 3 (CP-NC), whose upper flange has smaller dimensions, the difference between the curves becomes greater with time.

\subsubsection{Profile with box-type fire protection coating}

In Figure 12, the "temperature x time" curves can be observed for composite beams with box-type fire protection coating.

The "temperature $\mathrm{x}$ time" curves obtained by the standard method are the same in the parts of a same steel profile because a uniform temperature is considered along the profile. However, each part of the steel profile with box-type fire protection coating has different "temperature $x$ time" curves obtained by modeling in ABAQUS. It is possible to note that the curve obtained by the standard method was higher than the curve obtained by ABAQUS in the entire profile, for any profile analyzed and for the entire fire duration. The difference between these curves was greater over the fire duration. Comparing the results of steel profiles with different sizes, an increase in the size of the profile did not significantly influence the difference between the curves of the flanges and the web.

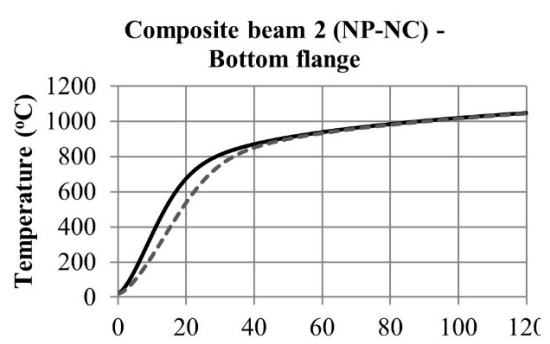

Composite beam 2 (NP-NC) - Web
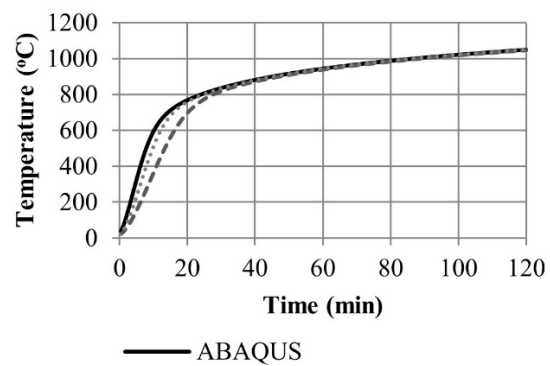

$-\cdots \cdot N B R 14323$

........ NBR 14323 (modified)

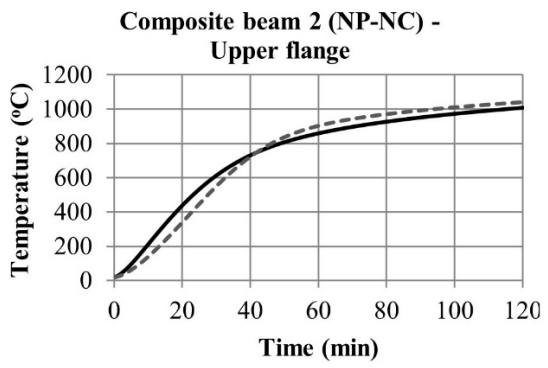

- ABAQUS --.-. NBR 14323

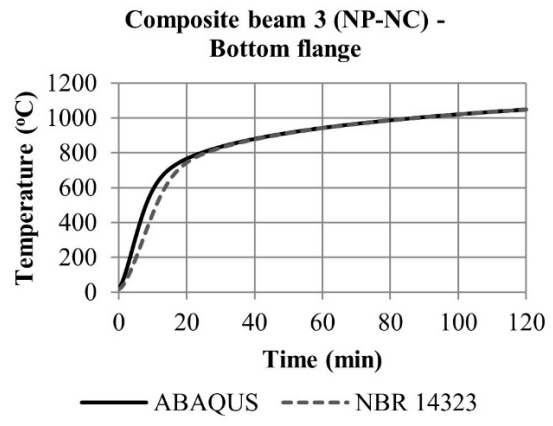

Composite beam 3 (NP-NC) - Web

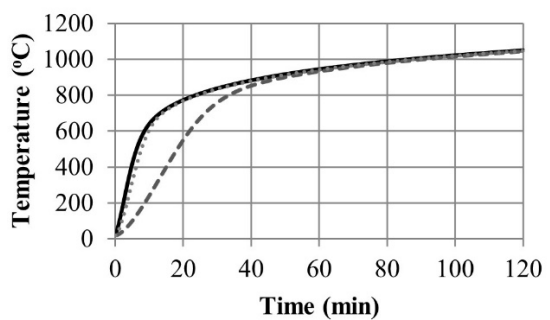

- ABAQUS

----・NBR 14323

........ NBR 14323 (modified)

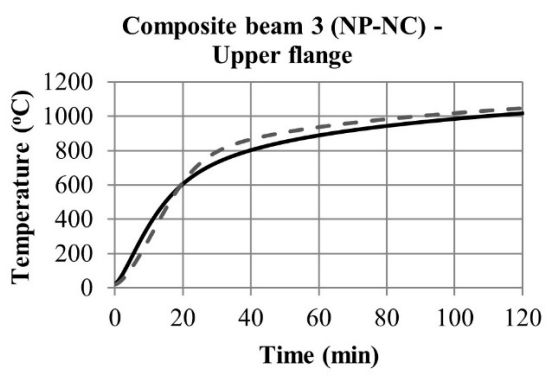

ABAQUS - - - NBR 14323

Figure 10. "Temperature $x$ time" curves obtained by the simplified method and by the advanced calculation method for the profiles of composite beams 2 (NP-NC) and 3 (NP-NC). 


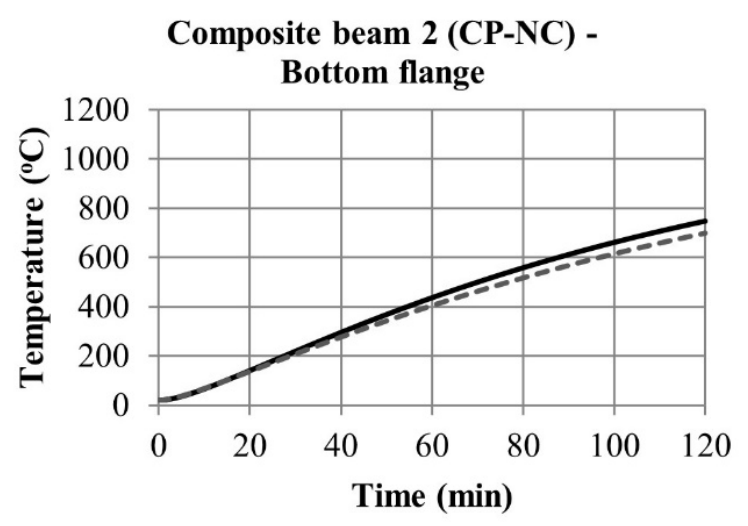

- ABAQUS ---・NBR 14323

Composite beam 2 (CP-NC) - Web

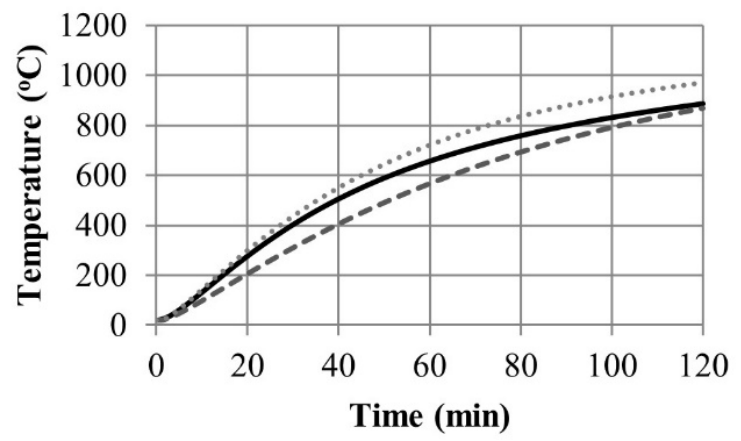

- ABAQUS

-.-.-NBR 14323

......... NBR 14323 (modified)

Composite beam 2 (CP-NC) Upper flange

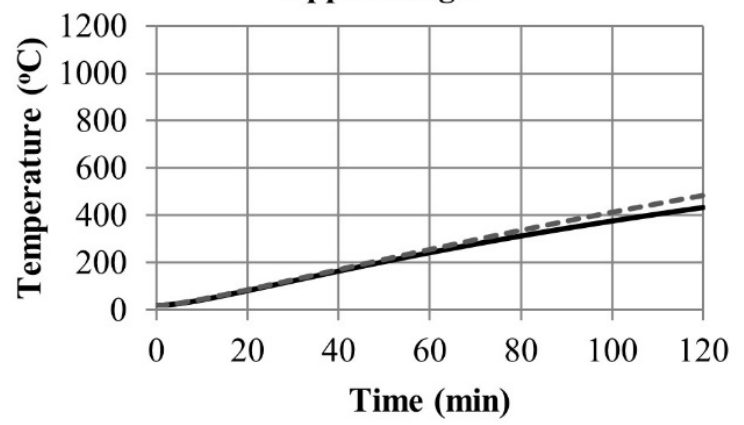

ABAQUS ----•NBR 14323
Composite beam 3 (CP-NC) Bottom flange

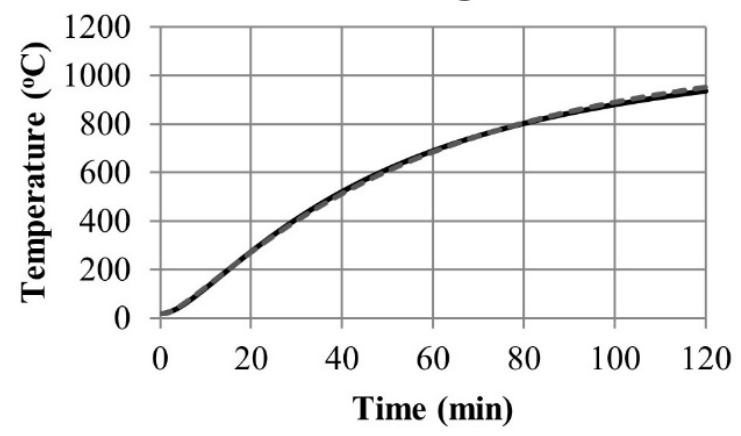

ABAQUS -----・NBR 14323

Composite beam 3 (CP-NC) - Web

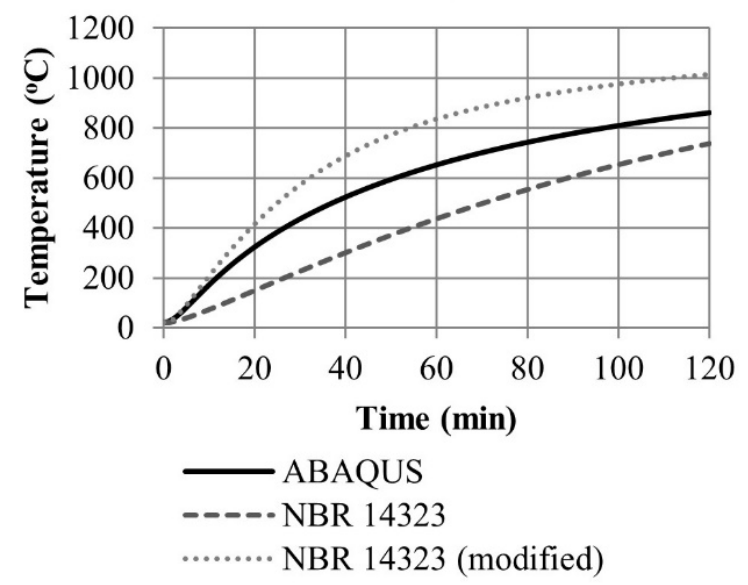

Composite beam 3 (CP-NC) Upper flange

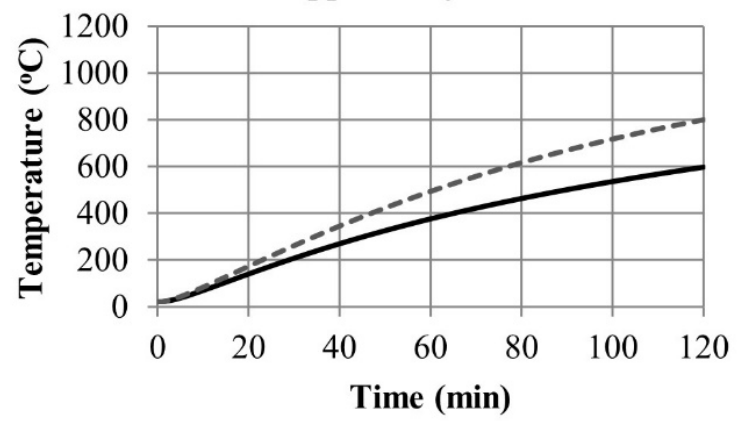

—ABAQUS ----NAR 14323

Figure 11. "Temperature $x$ time" curves obtained by the simplified method and by the advanced calculation method for the profiles of composite beams 2 (CP-NC) and 3 (CP-NC).

\subsubsection{Uniform temperature in the concrete slab sections}

This step allows to analyze, in ABAQUS, the temperature of the slab in two sections: one in the connector region (section 1) and the other located between the connector and the end of the effective width (section 2). For comparison with the results obtained using the method prescribed by ABNT NBR 14323:2013 [2], composite beam 2 with and without fire protection coating was used. Table 3 shows these temperatures over four fire times. 


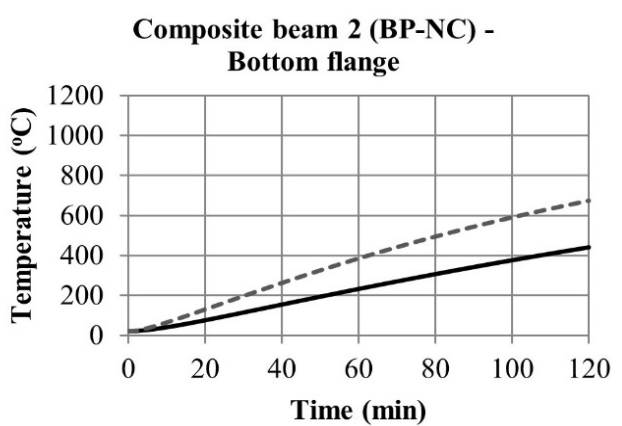

— ABAQUS -----NBR 14323

Composite beam 2 (BP-NC) - Web

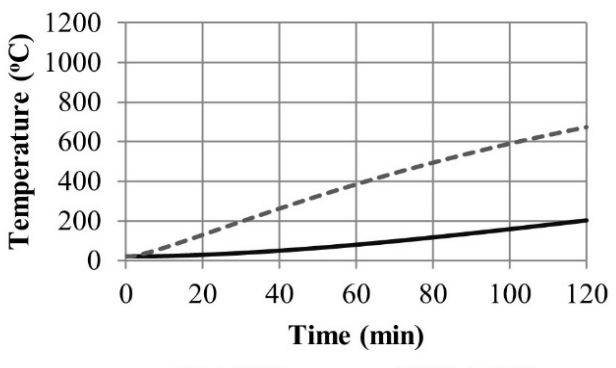

— ABAQUS ----..NBR 14323

Composite beam 2 (BP-NC) -

Upper flange

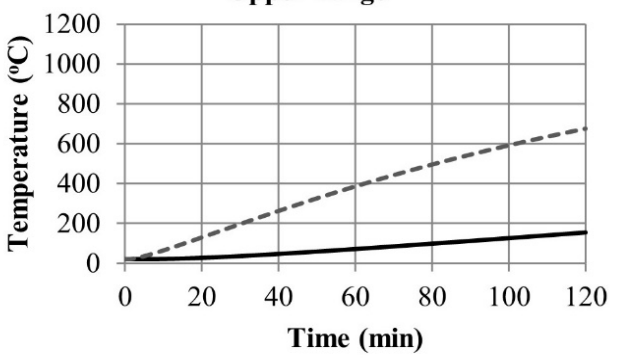

ABAQUS -.-...NBR 14323
Composite beam 3 (BP-NC) -

Bottom flange

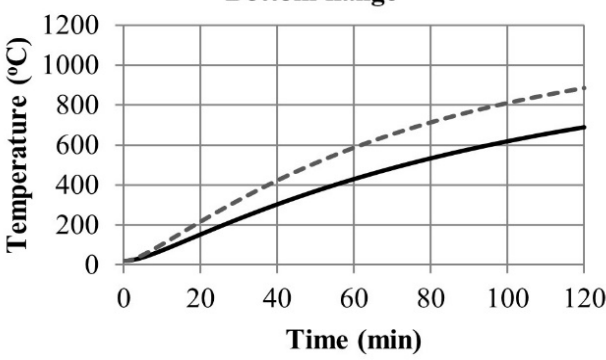

— ABAQUS ----.-NBR 14323

Composite beam 3 (BP-NC) - Web

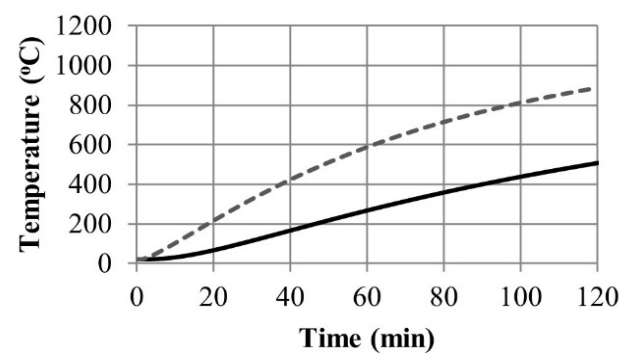

— ABAQUS ----.-NBR 14323

Composite beam 3 (BP-NC) Upper flange

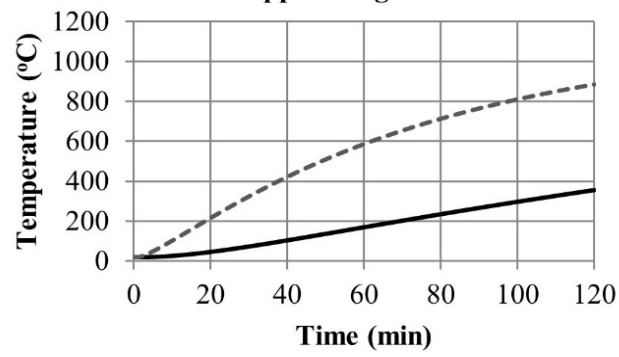

— ABAQUS ----・NBR 14323

Figure 12. "Temperature $x$ time" curves obtained by the simplified method and by the advanced calculation method for the profiles of composite beams 2 (BP-NC) and 3 (BP-NC).

Table 3. Uniform temperature in the concrete slab sections.

\begin{tabular}{|c|c|c|c|c|c|c|c|}
\hline \multirow{3}{*}{ Time (min) } & \multicolumn{7}{|c|}{ Temperature of concrete slab sections $\left({ }^{\circ} \mathrm{C}\right)$} \\
\hline & \multirow{2}{*}{ NBR 14323} & \multicolumn{3}{|c|}{ ABAQUS - Section 1} & \multicolumn{3}{|c|}{ ABAQUS - Section 2} \\
\hline & & 2 (NP-NC) & 2 (CP-NC) & 2 (BP-NC) & 2 (NP-NC) & 2 (CP-NC) & 2 (BP-NC) \\
\hline 30 & 190 & 155 & 41 & 23 & 214 & 213 & 213 \\
\hline 60 & 296 & 327 & 88 & 35 & 369 & 365 & 366 \\
\hline 90 & 343 & 459 & 146 & 55 & 488 & 479 & 480 \\
\hline 120 & 361 & 561 & 209 & 81 & 582 & 568 & 568 \\
\hline
\end{tabular}

ABNT NBR 14323:2013 [2] presents an equation to calculate a uniform temperature in the concrete slab that does not change neither with the properties of the concrete, nor with the type of profile and nor with the presence of a fire protection coating. For comparison, temperatures were determined in fourteen slices of the slab in ABAQUS and uniform temperatures were calculated using the Equation (11) from the standard. 
The temperatures in the concrete slab, both in section 1 and section 2 , are different from the values calculated according to the standard. The section 1 of the slab, along its height, presented a different temperature at certain time for each situation in which the steel profile is (with and without fire protection coating). Among the fire protection coatings used, the box-type fire protection coating resulted in lower temperature values and the slab showed higher temperatures when it had no fire protection coating. Section 2 presented the same temperature in any situation where the composite beam is subjected, depending only on the thermal properties of the concrete of the slab. This section, due to the highest temperatures, was considered the critical section of the concrete slab; therefore, it is the ideal section to compare with the values obtained using the standard method. In this section of the slab, the temperature found by ABAQUS was higher than the temperature found by the use of the standard equation, and this difference was greater with a longer fire duration.

The same composite beam 2 (NP-NC) was analyzed considering the thickness of the concrete slab equal to $7 \mathrm{~cm}$ through the two calculation methods. It was possible to note that the decrease in thickness increased the uniform temperature of the slab in the two sections, but still with the temperature obtained by ABAQUS higher than the temperature obtained by the standard equation. The minimum temperature reached by the concrete slab (section 2 surface not exposed to fire) is higher when the slab thickness is reduced, while the maximum concrete slab temperature (section 2 surface exposed to fire) has not changed significantly. The decrease in the slab height did not result in a modification in the "temperature $\mathrm{x}$ time" curve of the metallic beam upper flange.

\subsubsection{Connector temperature}

According to ABNT NBR 14323:2013 [2], the connector temperature can be considered, conservatively, equal to the highest temperature among those of the connected structural elements. However, this standard specifies that the design resistant force of a shear connector in fire situation must be determined at a temperature equivalent to $80 \%$ of the temperature of the upper flange of the steel profile. As can be seen in the graph of Figure 9, referring to the composite beam connector 1 (NP-C) used in item 4.1.3, the "temperature $\mathrm{x}$ time" curve of the connector is closer to the curve of the upper flange, and shows that this element reached the lowest maximum temperature of the composite section. It is possible to note that the temperature of the connector was, on average, equal to $80 \%$ of the temperature of the upper flange during the first 30 minutes of fire, and higher than $80 \%$ after that time.

\subsection{Analysis of composite beams without fire protection coating material}

This item aims to analyze, using ABAQUS, the temperature rising in the steel section as function of the mass factor and the dimensions ( $h, b f$, tw and tf) of each part of the steel section and, also, evaluate the development of the concrete slab temperature during the time of exposure to fire. For this analysis, composite beam 2 (NP-NC), with a larger dimension profile, composite beam 3 (NP-NC), with a smaller dimension profile, and the beam 4 (NP-NC), with intermediate dimension profile, were used.

\subsubsection{Influence of the mass factor}

Table 4 shows the values of the mass factors of the steel profiles and of each profiles parts. It is possible to note that the profile of the composite beam 3 (NP-NC), with lower linear mass, has the largest mass factor, as well as its parts. Comparing the results of each part of a profile, the web had a higher value of the mass factor, the bottom flange presented an intermediate value and the upper flange, being protected from fire in one side, presented the lowest factor.

Table 4. Mass factor of each part and of the metallic profiles of the composite beams 2 (NP-NC), 3 (NP-NC) e 4 (NP-NC).

\begin{tabular}{ccccc}
\hline \multirow{2}{*}{ Composite beam } & \multicolumn{4}{c}{ Mass factor $\left(\mathbf{m}^{\mathbf{- 1}}\right)$} \\
\cline { 2 - 5 } & Upper flange & Bottom flange & Web & Metallic profile \\
\hline 2 (NP-NC) & 46 & 86 & 250 & 110 \\
\hline $3($ NP-NC) & 115 & 220 & 421 & 235 \\
\hline 4 (NP-NC) & 87 & 167 & 317 & 194 \\
\hline
\end{tabular}

Figure 13 shows the "temperature $x$ time" curves of the parts of each profile used in this analysis, up to 40 minutes, to analyze the heating speed of the steel as a function of the mass factor. 
The first minutes of fire are the most important, once are when the profile temperature increases most rapidly. Comparing the "temperature $\mathrm{x}$ time" curves of each part of the profile, among the analyzed profiles, it is observed that the curves tended to be equivalent at some point.

The parts of the profile of the composite beam 3 (NP-NC), with smaller dimensions and greater mass factor, had a higher temperature increase. In contrast, the profile of the composite beam 2 (NP-NC), with less mass factor, took longer to heat up when subjected to high temperature, while the profile of the composite beam 4 (NP-NC) showed an intermediate temperature increase. It is observed that profile 3 (NP-NC) has a mass factor closer to profile 4 (NP-NC), and the "temperature x time" curves of these profiles are also closer. This behavior shows that a profile with a greater mass factor will present the slope of the "temperature $\mathrm{x}$ time" curve steeper, indicating that it has a faster temperature rise.
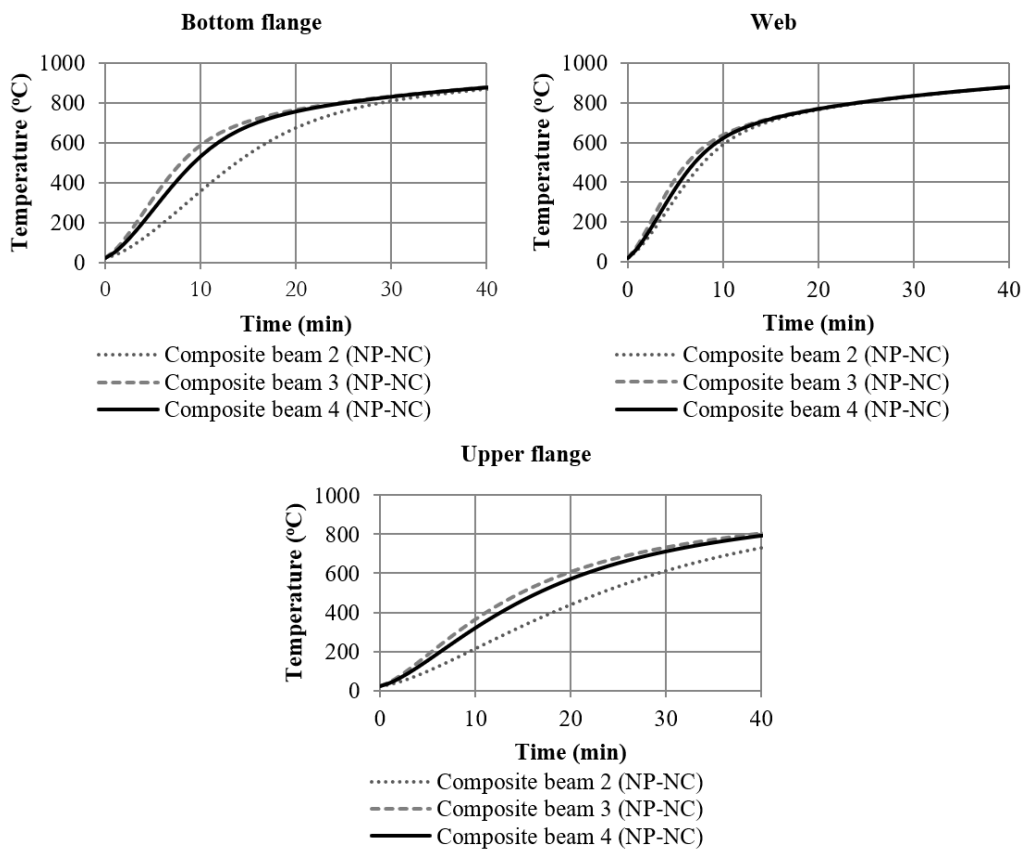

Figure 13. Temperature development in each part of the steel profiles up to 40 minutes.

\subsubsection{Uniform temperature in the concrete slab sections}

The uniform temperatures of the slabs of the composite beams 2 (NP-NC) and 3 (NP-NC) were analyzed, with the objective of verifying the influence of the profile mass factor in the analyzed sections. The temperature values for the two analyzed sections of each concrete slab are shown in Table 5. In section 1, the highest temperatures corresponded to the profile of the composite beam 3 (NP-NC), with the highest mass factor and the lowest linear mass. Therefore, the size of the metallic profile, mainly the length (bf) of the upper flange, influenced the temperature of the region where the shear connector is located. Hence, higher the mass factor of the profile, higher the temperature in the connector. The temperatures of section 2 of the concrete slab were practically the same for both profiles, showing that the size and mass factor of the profile did not influence the maximum temperature of the slab.

Table 5. Uniform temperature in the concrete slab sections of the composite beams 2 (NP-NC) and 3 (NP-NC).

\begin{tabular}{|c|c|c|c|c|}
\hline \multirow{3}{*}{ Time (min) } & \multicolumn{4}{|c|}{ Temperature of the concrete slab sections $\left({ }^{\circ} \mathrm{C}\right)$} \\
\hline & \multicolumn{2}{|c|}{ ABAQUS - Section 1} & \multicolumn{2}{|c|}{ ABAQUS - Section 2} \\
\hline & 2 (NP-NC) & 3 (NP-NC) & 2 (NP-NC) & 3 (NP-NC) \\
\hline 30 & 155 & 203 & 214 & 214 \\
\hline 60 & 327 & 365 & 369 & 370 \\
\hline 90 & 459 & 488 & 488 & 489 \\
\hline 120 & 561 & 584 & 582 & 584 \\
\hline
\end{tabular}




\subsection{Analysis of composite beams with fire protection coating material}

This analysis aims to evaluate the thermal performance of the composite beam with fire protection coating material and to verify which of the two types of fire protection coating types, contour or box, is the most efficient to delay the temperature rise in the composite beam. In addition, the influence of the variation in the properties of the fire protection coating material was analyzed. For this analysis, the ABAQUS was used for the numerical modeling of the composite beam 2 .

\subsection{1 "Temperature vs time" curve of the profile parts}

In Figure 14, the "temperature $x$ time" curves of the parts of the steel profile without fire protection coating, with contour-type fire protection coating and with box-type fire protection coating are found. With these curves, it is possible to verify the effect that the type of fire protection coating has on the heat retardation in steel.

The temperature of the steel profile can increase rapidly or not, depending on the degree of fire protection coating applied (or its absence). The use of fire protection coating prevented a very rapid temperature rise in the initial minutes, which can be observed when comparing the slope of the "temperature $\mathrm{x}$ time" curves of the profile with and without fire protection coating, and caused a decrease in temperature in all parts of the profile over the time.

With a contour-type fire protection coating, the upper flange showed a greater temperature drop in relation to the web and the bottom flange. The box-type fire protection coating showed the highest thermal efficiency, once it ensures that the surface affected by the fire is largely away from the steel profile. With this type of coating, the highest temperature is found on the bottom flange, while in the web, which is away from the surface affected by the fire due to the coating, the temperature is slightly higher than the temperature of the upper flange.
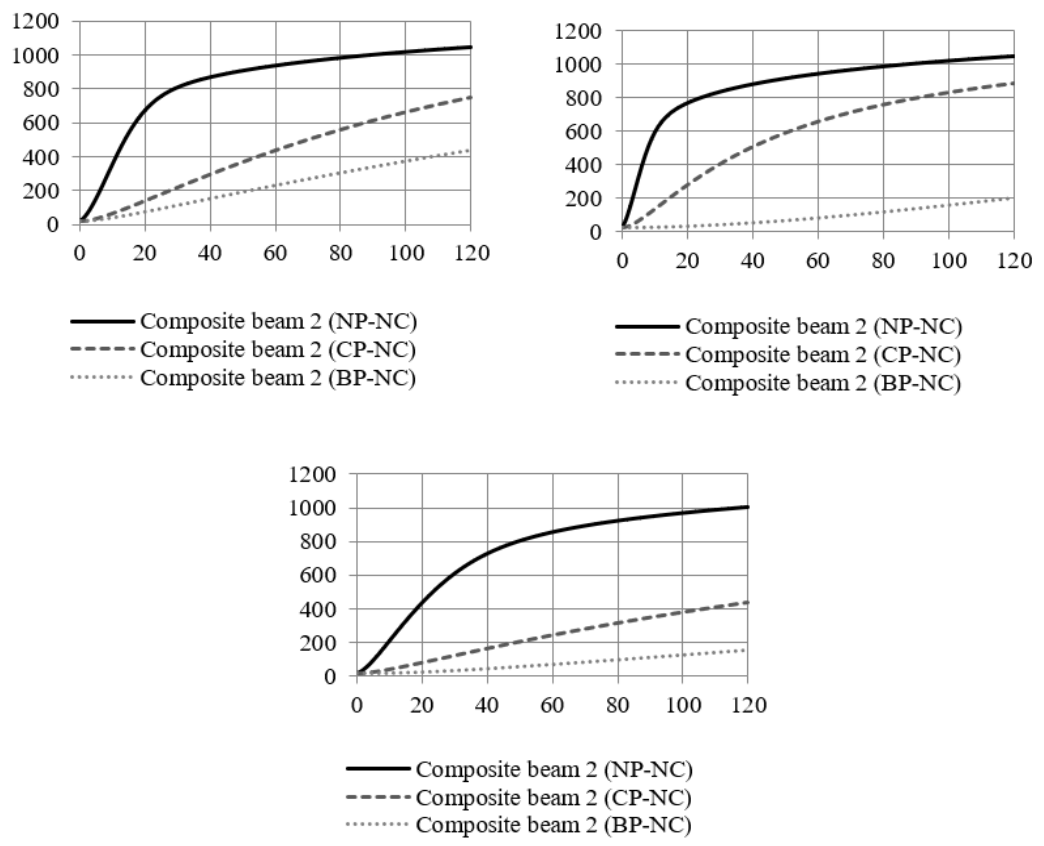

Figure 14. Temperature development in composite beam 2 with and without fire protection coating during the time of exposure to fire.

\subsubsection{Variation in the properties of the fire protection coating material}

This step makes it possible to analyze the influence of each thermal property and the thickness of the fire protection coating material. For this, the composite beam 2 was used as a reference for cases without fire protection coating, with contour-type fire protection coating and with box-type fire protection coating. The analyzed situations had only a thermal property or the thickness changed, with an increase of $20 \%$ of its value. Table 6 shows the reference values and the four cases analyzed, called cases (a), (b), (c) and (d). 
Table 6. Values of the properties of the fire protection coating material for the cases analyzed.

\begin{tabular}{cccccc}
\hline $\begin{array}{c}\text { Fire protection coating material } \\
\text { properties }\end{array}$ & Reference values & Case (a) & Case (b) & Case (c) & Case (d) \\
\hline Thermal conductivity $\left(\mathrm{W} / \mathrm{m}^{\circ}{ }^{\circ} \mathrm{C}\right)$ & 0.135 & 0.162 & 0.135 & 0.135 & 0.135 \\
\hline Specific mass $\left(\mathrm{kg} / \mathrm{m}^{3}\right)$ & 320 & 320 & 384 & 320 & 320 \\
\hline Specific heat $\left(\mathrm{J} / \mathrm{kg} \cdot{ }^{\circ} \mathrm{C}\right)$ & 1100 & 1100 & 1100 & 1320 & 1100 \\
\hline Thickness $(\mathrm{mm})$ & 13 & 13 & 13 & 13 & 15.6 \\
\hline
\end{tabular}

The graphs in Figure 15 show the "temperature x time" curves of the reference situation and the cases analyzed for the three parts of the steel profile, with a contour and box-type fire protection coating.

For the profile with contour-type fire protection coating, in case (a), when the thermal conductivity value increased, the "temperature $x$ time" curve for all parts of the profile was higher, unlike other situations, when the temperature of the profile tended to decrease with the increase of the properties. The most significant decrease in temperature occurred in case (d) when there was a variation in the thickness of the fire protection coating. In cases (b) and (c), the curves are close to the reference curve for all parts of the profile, that is, the increase in specific mass and heat generated an insignificant decrease in temperature for all profile parts.
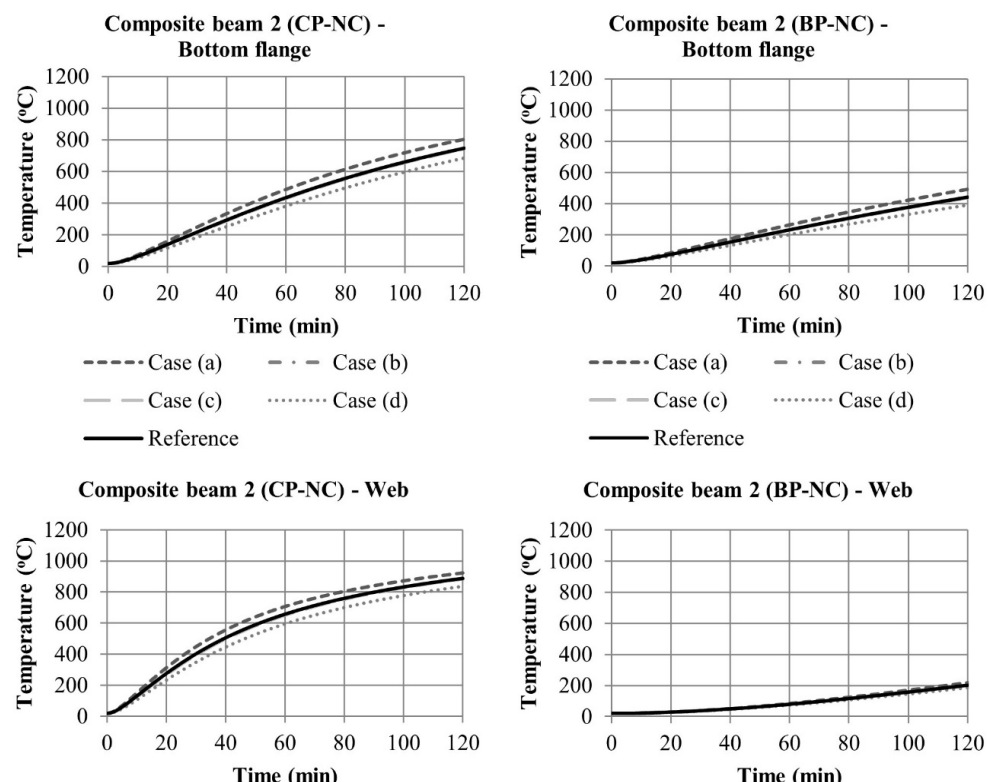

$$
\begin{aligned}
& \ldots-\text { Case (a) } \quad-\cdots-\text { Case (b) } \\
& - \text { Case (c) } \quad \ldots . . . . . \text { Case (d) } \\
& - \text { Reference }
\end{aligned}
$$

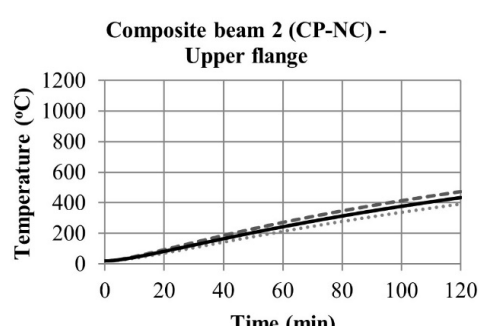$$
--- \text { Case (a) - - - Case (b) }
$$$$
\text { - Case (c) …..... Case (d) }
$$$$
\text { - Reference }
$$

Composite beam 2 (BP-NC) -

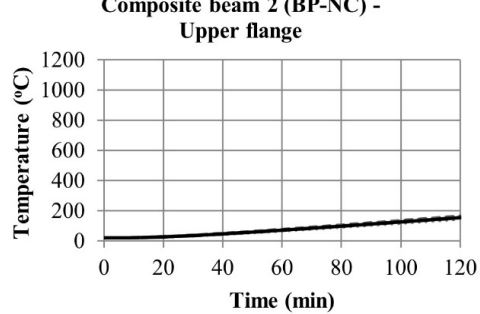

$$
\begin{aligned}
& -\cdots \text { Case (a) } \quad-\cdots \text { Case (b) } \\
& - \text { Case (c) } \quad \cdots . . . . \text { Case (d) } \\
& \text { Reference }
\end{aligned}
$$

$$
\begin{aligned}
& --- \text { Case (a) } \\
& -\cdots-\text { Case (b) } \\
& - \text { Case (c) } \cdots \cdots \cdot \text { Case (d) } \\
& \text { Reference }
\end{aligned}
$$

Figure 15. "Temperature $x$ time" curves of reference metallic profile and of the situations analyzed with contour and box-type fire protection coating. 
Regarding the box-type fire protection coating, the variation in properties had a similar influence to the use of the contour-type fire protection coating. It is possible to note a greater influence of the variations in the properties of the fire protection coating material on the bottom flange, where the difference between the "temperature $\mathrm{x}$ time" curves of the different cases and the reference was more accentuated. In relation to the upper flange and the web, changes made to any property of the fire protection coating material did not result in a significant variation in temperature.

\section{CONCLUSIONS}

In this paper, thermal analyzes of composite steel and concrete beams were carried out using numerical modeling and the simplified calculation proposed by ABNT NBR 14323:2013 [2], with the main result being conclusions about the thermal behavior of the composite cross-section, in addition to the importance of considering fire protection coating. Considering these results, it can be concluded for the analysis of thermal behavior that:

- The temperature of the entire composite system without fire protection coating has increased over the time, as expected;

- The profile, connector and concrete slab presented a non-uniform temperature field over the duration of the fire, as expected;

- The presence of the shear connector decreased the maximum temperature reached on the upper flange.

By comparing the two methods of thermal analysis (ABAQUS and Brazilian Standard), the following conclusions are reached:

- For all parts of the profile with and without fire protection coating, the "temperature $\mathrm{x}$ time" curve obtained by modeling in ABAQUS had the same trend as the curve obtained by the use of the ABNT NBR 14323:2013 [2] method, as expected;

- There was a better agreement between the "temperature $x$ time" curves of the web of a profile without fire protection coating, obtained by the standard equation and by numerical modeling, when the mass factor was changed for the profile without fire protection coating, which it is justified by the fact that the equation proposed in the present paper was determined from the definition of the mass factor and provides the correct unit for this factor, which does not occur with the unit of the standard equation;

- It can be seen from the graphs that the results obtained with the use of the web mass factor equation proposed by the standard are lower than the results obtained by numerical modeling in the first 40 minutes of fire of the composite beam without fire protection coating and in all fire duration in the composite beam with contour-type fire protection coating, which indicates that, in these cases, the values obtained by the standard equation are against safety;

- It is evident that the greatest discrepancy, comparing the profiles without and with fire protection coating, occurred for the case with the box-type fire protection coating. This is due to the fact that the standard presents equations that were developed assuming a uniform temperature distribution in the steel profile;

- The slab had the highest temperatures in section 2. This section, considered the critical section, has the same temperatures, regardless of the profile conditions;

- In a simplified form, the temperature of the connector can be considered equal to the temperature of the upper flange. In the analysis of composite beams without fire protection coating material, the following conclusions can be drawn:

- The temperature increase rate of the steel profile in fire situation is proportional to its mass factor. Hence, a greater mass factor caused a "temperature $\mathrm{x}$ time" curve of the parts of the profile that were more steep, as expected;

- The size of the steel profile did not influence the temperature of section 2 of the slab. In the analysis of composite beams with fire protection coating material, the following conclusions can be drawn:

- The use of both types of fire protection coating was efficient to delay the access of heat to steel, mainly for boxtype fire protection coating;

- The modification in the properties of the fire protection coating material and in the geometry caused a greater difference when the profile has a contour-type fire protection coating. To have the lowest temperatures in steel, the correct is to use fire-retardant coating materials with higher values of specific mass, specific heat and thickness. However, a higher specific mass causes an increase in the weight of the structure and an increase in thickness can generate a higher material cost.

\section{ACKNOWLEDGEMENTS}

The authors would like to thank the Coordenação de Aperfeiçoamento de Pessoal de Nivel Superior (CAPES) and the Universidade Estadual do Norte Fluminense Darcy Ribeiro (UENF) for financial support given to the development of the research in question. 


\section{REFERENCES}

[1] SIMULIA. ABAQUS Software. Version 6.14. Dassault Systèmes, 2014.

[2] Associação Brasileira de Normas Técnicas, Projeto de estruturas de aço e de estruturas mistas de aço e concreto de edificios em situação de incêndio - Procedimento, ABNT NBR 14323, 2013. Accessed: Jul. 16, 2017. [Online]. Available: https://www.abntcatalogo.com.br/norma.aspx?ID=260570

[3] Y. C. Wang, Steel and Composite Structures - Behaviour and Design for Fire Safety, $1^{\text {st }}$ ed. London and New York: Spon Press, 2002.

[4] P. C. Jain and M. N. G. Rao, “Analysis of steel frames under fire environment,” Int. J. Numer. Methods Eng., vol. 19, pp. 1467-1478, 1983., http://dx.doi.org/10.1002/nme.1620191005.

[5] I. W. Burgess, J. A. El-Rimawi, and R. J. Plank, “Analysis of beams with non-uniform temperature profile due to fire exposure,” $J$. Construct. Steel Res., vol. 16, pp. 169-192, 1990., http://dx.doi.org/10.1016/0143-974X(90)90008-5.

[6] Y. C. Wang, “Composite beams with partial fire protection,” Fire Saf. J., vol. 30, pp. 315-332, 1998. http://dx.doi.org/10.1016/S0379-7112(97)00000-3.

[7] R. Cazeli, P. M. M. Vila Real, V. P. Siva, and P. A. G. Piloto “Análise numérica de vigas I de aço em situação de incêndio, sujeitas à flambagem lateral. Contribuição para a validação de uma proposta de revisão do Eurocode 3 - Parte 1.2”, In IV Seminário Internacional "O uso de Estruturas Metálicas na Construção Civil” e I Congresso Internacional de Construção Metálica - I CICOM, São Paulo, Brazil, 2001. Accessed: March 30, 2017. [Online]. Available: http://hdl.handle.net/10198/2092

[8] M. B. Wong and J. I. Ghojel, "Sensitivity analysis of heat transfer formulations for insulated structural steel components," Fire Saf. J., vol. 38, pp. 187-201, 2003. http://dx.doi.org/10.1016/S0379-7112(02)00057-7.

[9] European Committee for Standardization, Design of steel structures. General rules - Structural fire design. Eurocode 3, EN 1993-12, 2005. Accessed: July 20, 2017. [Online]. Available: https://eurocodes.jrc.ec.europa.eu/showpage.php?id=133

[10] J. C. L. Ribeiro "Simulação via método dos elementos finitos da distribuição tridimensional de temperatura em estruturas em situação de incêndio", M.S. thesis, Departamento de Eng. Estruturas - DEES, Universidade Federal de Minas Gerais - UFMG, Belo Horizonte, MG, Brazil, 2004. [Online]. Available: http://hdl.handle.net/1843/FACO-6AYG27

[11] Associação Brasileira de Normas Técnicas, Dimensionamento de estruturas de aço de edifícios em situação de incêndio Procedimento, ABNT NBR 14323, 1999.

[12] L. D. T. Rodrigues "Determinação numérica e analítica da carga crítica uniformemente distribuída de vigas de aço em situação de incêndio natural”, M.S. thesis, ENC, UnB/FT, Brasília, Brazil, 2013. [Online]. Available: https://repositorio.unb.br/handle/10482/14068

[13] F. M. Rocha and J. Munaiar No, “Análise de vigas mistas de aço e concreto pertencentes a pisos de baixa altura em situação de incêndio: ênfase à influência dos modelos constitutivos do concreto," Rev. IBRACON Estrut. Mater., vol. 7, pp. 158-177, 2014., http://dx.doi.org/10.1590/S1983-41952014000100008.

[14] E. C. Fischer and A. H. Varma, "Fire behavior of composite beams with simple connections: Benchmarking of numerical models," J. Construct. Steel Res., vol. 111, pp. 112-125, 2015. http://dx.doi.org/10.1016/j.jcsr.2015.03.013.

[15] A. R. Melão "Sobre perfis I de aço em situação de incêndio paramétrico", M.S. thesis, PEF, EPUSP, São Paulo, Brazil, 2016. [Online]. Available: https://www.teses.usp.br/teses/disponiveis/3/3144/tde-02122016-090138/pt-br.php

[16] Associação Brasileira de Normas Técnicas, Componentes construtivos estruturais - determinação da resistência ao fogo, ABNT NBR 5628, Rio de Janeiro, 2001. [Online]. Available: https://www.abntcatalogo.com.br/norma.aspx?ID=2529

[17] Associação Brasileira de Normas Técnicas, Exigências de resistência ao fogo de elementos construtivos de edificações Procedimento, ABNT NBR 14432, 2001. [Online]. Available: https://www.abntcatalogo.com.br/norma.aspx?ID=2541

[18] Associação Brasileira de Normas Técnicas, Perfil I estrutural de aço soldado por arco elétrico - Requisitos gerais, ABNT NBR 5884, 2013. [Online]. Available: https://www.abntcatalogo.com.br/norma.aspx?ID=255454

[19] European Committee for Standardization, Design of concrete structures. General rules - Structural fire design, Eurocode 2 - EN 1992-1-2, Bruxelas, 2004. [Online]. Available: https://eurocodes.jrc.ec.europa.eu/showpage.php?id=132

[20] European Committee for Standardization, Actions on structures. General actions - Actions on structures exposed to fire, Eurocode 1 - EN 1991-1-2, Bruxelas, 2002. [Online]. Available: https://eurocodes.jrc.ec.europa.eu/showpage.php?id=131

[21] Associação Brasileira de Normas Técnicas, Projeto de estruturas de concreto em situação de incêndio, ABNT NBR $15200,2012$. [Online]. Available: https://www.abntcatalogo.com.br/norma.aspx?ID=90682

Author contributions: MSFD: development of the work, analysis and writing; VJK: general supervision.

Editors: Leandro Mouta Trautwein, José Luiz Antunes de Oliveira e Sousa, Guilherme Aris Parsekian. 